DOI: $10.15503 /$ jecs20141-334-344

334

Local cultures and societies

\title{
THE ACQUISITION OF THE LATVIAN LANGUAGE AS THE SECOND LANGUAGE AT PRESCHOOL AGE IN THEORY AND PRACTICE
}

\author{
INGĒRA TOMME-JUKĒVICA \\ Faculty of Translation Studies, Ventspils University College, \\ ,QSHOHX6WHW $\$$ \$ 9 HOWSIQ/DWID \\ E-mail address: tomme-jukevica@inbox.lv
}

\begin{abstract}
In Latvia there are no substantial studies on bilingual preschool children's Latvian language as the second language. The article provides an overview of the $20^{\text {th }}-21^{\text {st }}$ century linguistic theories in the context of child second language acquisition as well as raises awareness about their influence on and use in the learning of preschoolers whose second language is Latvian, carrying out content analysis of the Minority Preschool Education Program (with instruction in Russian), the Latvian Language Program of X preschool education establishment, teaching resources (teaching aid kits, didactic handouts) as well as the Latvian language as the second language study content.

The conclusion is drawn that the theory of communicative competence and the systemic functional grammar theory prevail as well as the basic principles of the behavioral theory can be discerned. In the teaching resources and learning process it is advisable to more often incorporate the same language material repetition in different situations and new combinations. Consideration must be given to more positive and negative transfer (interference) emphasis. To prevent children's errors it is advisable to provide and incorporate special exercises in the teaching resources as well as methodological recommendations for the Latvian language teachers.
\end{abstract}

Key words: child second language acquisition, linguistic theories, curricula, teaching resources

\section{INTRODUCTION}

In Latvian linguistics the child language research is still at its initial stage, while the research of particular language facts, phenomena etc. is carried out. However, bilingual preschool children's Latvian language as the second language is not being analyzed in large-scale. There is a lack of research on preschool children second language (Latvian) acquisition and on its quality. This article aims to provide an overview of the $20^{\text {th }}-21^{\text {st }}$ century linguistic theories of child second language acquisition in context, and to identify how they affect and are used in preschool age children Latvian as a second language learning. 
The paper presents content analysis of the Minority Preschool Education Program (with instruction in Russian) (Program, 2012), the Latvian Language Program of Riga X preschool education establishment (Program, 2008), a teaching aids kit "Tip Top" (Eglìte, 2012a; Eglīte, 2012b), didactic handouts "Kabata" (Valdmane, 2012) and Latvian as second language lesson.

The data for qualitative analysis were collected in the form of educational documents, the teaching aids kit, didactic handouts, the Latvian language lesson observation, an interview with a Latvian language teacher. For data treatment we used content analysis of the scripts of the interview with the Latvian language teacher, video observation of two Latvian language lessons, educational documents, the teaching aids kit, the didactic handouts.

\section{LINGUISTIC THEORIES OF CHILD SECOND LANGUAGE ACQUISITION}

Both general linguistics and some special branches of linguistics developed the language research theoretical principles as well as analyzed and characterized the language system. We use the most important findings of these studies to form the theoretical basis of language acquisition. In addition to the studies of traditional general linguistics and specific linguistic branches such as phonetics, phonology, grammar, semantics, etc., some other studies are becoming popular. We can mention the research in pragmatics, cognitive linguistics, psycholinguistics, neurolinguistics etc. Along with the development of lingual didactics we have started to apply a wider range of approaches, methods and techniques of language acquisition.

In Latvia the Communicative Approach overshadows the initially dominant Formal Grammatical Approach to Latvian as the second language learning. One can notice the use of other approaches as well. The theory of communicative competence closely relates to the issues of the Communicative Approach concerning the native, second and foreign languages learning. This theory, along with other theories each in their own way, affected the child second language learning and research. Among other influential theories one can mention behaviorism, universal grammar, the monitor model, systemic functional grammar and usage-based theory of language acquisition.

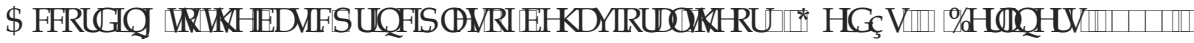
where speech is interpreted as the chain of physiological stimuli and responses, a child learns the second language from the language patterns. A child repeats and imitates what the teacher says. Re-combining the two things or phenomena, when the teacher points to the boy and says puika (a boy), a child learns what it means. A child learns particular words through the teacher's demonstration, presented objects or pictures, by repeating the words, pointing to the object or touching it. In this way, a child acquires the bulk of the second language vocabulary. As children learn language by imitation, a major focus is on the development of listening skills.

Noam Chomsky's theory of universal grammar (Chomsky, 2006) indirectly affected the child second language research. It had an effect on the subject of the 
research and methodology. For example, the tasks in which a judgment on the truth of the expression must be expressed with yes/ no. The researchers ask the children to tell whether a sentence is constructed grammatically correct. Even if the sentence is rare for real communication or we do not use it at all. In the tasks, in which judgment on grammatical correctness must be expressed, children hear the sentences like "The Magician disappeared in the Rabbit". The action or image illustrates this sentence. A child has to assess which one is an acceptable expression ("true" /"false"), using a binary or more detailed scale.

Nowadays, Stephen Krashen's monitor theory and model (Krashen, 1982), involving the language learning process analysis is the most frequently mentioned second language acquisition theory in child language research. Monitor model consists of five basic hypotheses. These hypotheses are the following: the language learning and teaching hypothesis, the natural sequence hypothesis, the monitor hypothesis, the linguistic information or input hypothesis and the emotional filter hypothesis. One must take into account the mentioned hypotheses when analyzing second language acquisition. According to the language learning and teaching hypothesis, a child can acquire the skills of the Latvian language as the second language in two ways:

1. Through natural language acquisition, i.e. unconsciously, similarly to the way children learn their native language - during the communication process. In this case the language is a tool, but not a goal. This approach is also offered in a number of nurseries in Europe and in other countries as immersion programs. It is also used in other models of bilingual education (Mickeviča \& Visocka, 2008). Natural language learning is also possible in Latvia in circumstances when the Russophone child goes to the kindergarten or a small nursery group in which Latvian is the language of instruction. Again, language learning takes place during the naturally relaxed communication process.

2. Through learning, i.e. acquiring the language deliberately and developing the language skills purposefully. In this case, learning is a conscious process in which the learner learns something "about the language." As a rule during this process we analyze and correct the learner's errors (Beikers, 2002, p. 95). This kind of teaching is typical for the Latvian as second language acquisition in the minority kindergartens. Here we can also observe the efforts to ensure the informal language environment. This environment motivates learners to learn the language through play and provides guidance in Latvian in real everyday situations.

S. Krashen's monitor theory provides rationale for the communicative and content-based learning. It also characterizes the insufficient role of the teaching environment in language acquisition (Krashen, 1982).

According to Dell Hymes's communicative competence theory, a child acquires sentences not only as pragmatic units, but also as speech units that are appropriate for a particular context in which they originate. In such a way the child acquires not only linguistic competence, but also communicative competence. This means that in the process of imitation a child absorbs not only certain phrases or expressions, but 
also fixes them along with the situation in which the phrase or expression was used. Thus again in the same or similar situation, a child is able to decode and accordingly use the combination of the language elements that he/she heard (Laiveniece, 2002, pp. 235-236). D. Hymes's communicative competence theory in the second language acquisition led to focus on the development of the children's communicative abilities, rather than the development of the mechanical language skills.

Michael Halliday's systemic functional grammar (Halliday, 1973) and John Searle's speech act theory (Searle, 2003) highlight the grammar acquisition perspective: from function to form. In addition, they put emphasis on the necessity of discourse analysis in the child second language acquisition process and research. Functional theory followers' works focus on the importance of a child's cognitive development and the role of social interaction in language acquisition. The child's language reflects his/her cognitive and emotional abilities, accordingly, his/ her previous knowledge about the world influence the child language. Cognitive structures take shape gradually, language learning is an individual creative process based on the definite laws and is related to the social development relationship (Šalme, 2013, p. 23).

In recent years, within the context of child second language acquisition, scientific literature often mentions usage-based theories. These theories are largely based on constructivist theories of language acquisition (Tomasello, 2006) as well as on functional linguistics, neuropsycholinguistics and neurolinguistics scholarly research theses. The key parameter of language acquisition is the input that a child receives. The importance of input for second language acquisition is the same as for native language acquisition (MacWhinney, 2008). For language acquisition at the productive level the language learner must have a wide range of vocabulary. This is necessary to infer abstract regularities from the specific cases of language use. The authors of these theories do not distinguish between lexical competence and grammatical competence. They also emphasize that lexical competence includes not only the knowledge of individual words, but also phrases and groups of words. In turn, they are already associated with the mediated learning of the grammatical regularities. The fixed expressions consisting of several words are taught and used as a whole. Similarly, we teach the phrases that express some functions, such as greeting or farewell (Good bye! See you tomorrow!). Structures are the major language acquisition units. They represent the implementation of the most direct language learner's communicative intention.

Nick Ellis, in relation to language learning and acquisition, mentions several guiding principles of the usage-based theories:

- language is inextricably linked to human cognition, perception, attention, learning, categorization, schematization processes, as well as memory;

- language as to its very nature is symbolic, it consists of a set of structured constructions, which consist in generally accepted meaning and form pairs, which are used for communicative purposes;

- knowledge of the language consists of linguistic constructions of different levels of complexity and abstraction. Constructions may include concrete and specific language units (e.g., single words and idioms), or combina- 
tions of complex concrete and abstract language segments (as it is in mixed structures). Thus, vocabulary is not strictly separated from grammar;

- constructions can be simultaneously represented and stored in a number of forms, characterized by different levels of abstraction;

- linguistic constructions (e.g., the cause of motion constructions: $X$ causes $\mathrm{Y}$ to move in $\mathrm{Z}$ direction or to a particular place - "He pushed it" may be linguistic symbols, which have a certain sense, existing separately from the specific lexeme. However, the constructions and some lexemes, of which they are composed, resonate with each other, therefore grammar and vocabulary are inseparable;

- language structures emerge from usage in particular context. Language development is slow and gradual, moving from the initial usage of language specific units to more abstract language schemes. This process depends on the type and frequency of lexemes with which certain constructions appear on the inputs. Lexeme storage is dependent on the frequency of lexeme coding but schematization depends on the frequency of the occurrence of the types of lexemes (Ellis, 2013).

In usage-based theories researchers claim that the child second language acquisition is based on some general cognitive processes. Language learning is driven by the general language learning mechanisms (e.g., frequency, analogy, word form selection, etc.). The differences may occur under the influence of "other" language. A second language can only be affected by what makes up the first linguistic "repertoire". Joan Bybee, describing the transfer of language, states that second language learners can transfer the constructions from their first language to a second language basing on their commonalities (Bybee, 2008; quoted from Blom, Paradis, \& Duncan, 2012, p. 6). Virginia Gathercole, on the other hand, concludes that bilingual children can transfer patterns from one language to another if they are similar enough to encourage transfer, and abstract enough not to rely on lexically specific information (Gathercole, 2007; quoted from Blom, Paradis, \& Duncan, 2012, p. 6).

Česlava Celitāne recognizes that the mother tongue has a special role in second language acquisition. She believes that the mutual influence of the languages is positive in the language learning process. She indicates that it is a great pedagogical success that by teaching the Latvian language, we can build on the child's native language. The child transfers the native language regularities to his/her second language. If they match, the second language is correct, if there are some other regularities, the second language is erroneous (Celitāne, 2007, p. 10).

Each of the above mentioned theories has affected the Latvian language teaching as the second language to a greater or lesser extent. To better understand the preschool education curriculum of Latvian as the second language and find out which ones are the prevailing theories in Latvia, hereinafter we examine the Minority Preschool Education Program (with instruction in Russian) (Program 2012), the Latvian Language Program of $X$ preschool education establishment (Program 2008), the teaching aids kit "Tip top" (Eglite, 2012a; Eglìte, 2012b) and the didactic handouts „Kabata” (Valdmane, 2012), as well as the Latvian language as the second language study content. 


\section{THE REFLECTION OF LINGUISTIC THEORIES IN STUDY PROGRAMS, TEACHING RESOURCES AND PRACTICAL LESSONS}

The content of each subject consists of subject matter, which, together with the learning tasks and exercises is included in textbooks or teaching resources and in study programs (Laiveniece, 2000, p. 103). Content analysis reveals concepts encoded in textbooks, understanding of how to teach the subject specified. Textbooks reflect topical issues in lingual didactics and methodology so - the potential of teaching the subject in a certain period of time, but they do not reflect the teacher's actual activities in class and do not reveal whether these opportunities are used (Lazdina, \& Šalme 2008, p. 70). Therefore, a situation is possible when, for example, some essential aspects of lingual didactics are not reflected in the program, but in practice the teacher uses them actively.

The analysis of learning objectives, tasks, methods, methodological approaches and forms of work organization in Minority Preschool Education Program (Program, 2012), shows that preschool language learners are prepared for real communication situations. Learning objective in the acquisition of the Latvian language, formulated in the Program, is "to promote the acquisition of basic listening and speaking skills, develop positive attitude towards the Latvian language as the state language" (Program, 2012, p. 20), but one of the tasks indicated in the Program is "to encourage the use of the acquired Latvian language in everyday life" (Program, 2012, p. 20). Additionally, the task of developing children's language in a social and cultural context is set: "to introduce the Latvian culture, celebrations and traditions" (Program, 2012, p. 20). Learning content components are communicative competence, language competence and socio-cultural competence, respectively, knowledge, skills and attitude, necessary for their formation.

At the basis of language acquisition is the communicative approach; language is used for the purposes of communication through play, children "participate in fairy tales, poem dramatization, role playing" (Program, 2012, p. 21). The program alone does not distinguish communicative competence functions and sub-functions, but indicates that children greet and say their farewells, perform simple instructions like, $l \bar{u} d z u$, atnes, noliec [please bring, put]; using the words of politeness: lüdzu, paldies [please, thank you], talk about themselves: for example, how old they are, answer questions about themselves, their family; talk about the weather; say their address; say short seasonal greetings, birthday wishes; form a sentence, make a short story about a picture (Program, 2012, pp. 20-21). The program does not specify a minimum learning material (specific grammatical categories, words, word combinations that children must acquire obligatory). In order to develop the language competence children should be able to pronounce the Latvian language sounds and sound connections (long vowels $\bar{a}, \bar{e}, \bar{i}, \bar{u}$ and diphthongs $o$, ie, ai, ei, count to 5 and use ordinal numbers in their speech, name and use prepositions $u z$, zem, pie, aiz [to, below, at, behind] together with nouns (Program, 2012, pp. 20-21). In the Program there are no indications concerning adjectives, pronouns, and their alignment with the noun in the singular and the plural, adverbs, verbs. But in practice, children also learn these language units. 
Analyzing the Latvian Language Program of Riga X preschool education institution (Program, 2008), we found that the children are introduced to and practice using personal pronouns $e s, t u, m e \bar{s}, j \bar{u} s$ [I, you, we, you], demonstrative pronouns tas, $t \bar{a}$, tie, tās [this, that, these, those], possessive pronouns mans, tavs [my, your], interrogative pronouns kas?, kurš?, kura?, käds?, kāda? [what?, who?, whose?], adverbs indicating place šeit, tur, tuvu, tālu [here, there, near, far], action directions augšă, lejā, uz priekšu, atpakal, pa labi, pa kreisi, iekšă, ārā [upwards, downwards, forward, backward, to the right, to the left, in, out], time vakar, šodien, rit [yesterday, today, tomorrow] (Program, 2008). X pre-school teacher of the Latvian language explained that with these language units, "children make up sentences."

For the acquisition of language lexical units the Minority Preschool Education Program identifies thematic groups and gives some examples within certain themes that children should learn. "Say: words denoting objects, features of living beings and their characteristics, parts of your body, for example, galva, roka [head, hand], objects (toys) that are used in everyday life; domestic animals, for example, kakis, suns [cat, dog]; basic colors; daily activities, for example, éd, gul [eat, sleep]; family members, their names; objects, 3-4 animals living in Latvia; baby animals; natural phenomena describing seasons, for example, saule, vējš [sun, wind]; various activities (animal, human); some professions and the necessary tools, for example, skolotājs, tāfele, sētnieks, slota [teacher, blackboard, janitor, broom]" (Program, 2012, p. 20). We positively evaluate the fact that in X preschool Latvian language Program in concrete thematic groups is also given a minimum of specific language lexical units (words, phrases, sentences making samples, plays and poems) that children should learn (Program, 2008). However, we admit that the units to be acquired are not necessarily frequently used in everyday communication (for example, children have to know the Latvian names of a number of birds).

In the analyzed teaching resources we observed that not all lexical items included reflect child's cognitive and emotional abilities, for example, in didactic handouts "Kabata" (Pocket), designed for 4-7 year olds (Valdmane, 2012), some words are not in accordance with the preschool age children experience, interests and needs, e.g., izkapts, P Hǵines [scythe, lace], they are not modern, e.g., nुieburs [bodice] and are difficult to pronounce, e.g. brunurupucis [turtle]. Several word games are intended for older children, because they assume that the child already knows Latvian letters, can read and write them (In Minority Preschool Education Program there are no such requirements). Also in the set of teaching aids "Tip Top", provided for 6-year-olds (Eglite, 2012a), some words, e.g., ziemelis, niedre [northern wind, reed] are not very topical, but in general, children's language lexis to be learned is relevant to child experience, these are necessary and modern language forms used in everyday life.

Teaching aids kit "Tip Top" provides that a child acquires communication skills in real everyday situations: participates at Christmas, Martin day, Easter celebrations; chants folk songs about winter and Christmas, Martin day, Easter; participates in movement games, sings songs, solves puzzles; gives commands, playing games and movement games: Klausies!, Parädi! [Listen!, Show!] or in simulated everyday situations communicates with store seller, in a vehicle - with the driver. 
We can observe the influence of D. Hymes's theory of communicative competence and M. Halliday's systemic functional grammar. Evidence of this is the knowledge and skills children are intended to learn. Children acquire language in the context, expressing a variety of communicative functions of language. Phrases, short sentences are acquired as pragmatic units to name something, describe it (representative function): goods bought at shop; toys in the room; live body and object properties. Children learn to compose simple descriptive riddles; to greet others, say farewell, introduce oneself, ask and answer; express gratitude and request, give commands and instructions (regulating function); learn to say their name and ask other people's names; ask others questions: Cik maksā? , Kur brauksi? [How much is it? Where are you going?], and answer them. Children respond to questions about a picture; use politeness phrases in communication: Lüdzu!, Paldies! [Please! Thank you!]; Lüdzu, vienu biletii! - Paldies! [A ticket, please! - Thank you!]. Playing games and movement games children learn to give commands: Klausies!, Atver!, Parädi! [Listen! Open! Show!], as well as they learn to show their attitude, express emotions: satisfaction / dissatisfaction, pleasure / displeasure (personal function): for example, express liking or disliking of some food, make a choice (want / don't want) regarding toys; engage in imaginary situation (imaginative function): for example, listen to a short fairy tale about seasons and make short sentences about it, go into characters, express appropriate emotions (Eglite, 2012a). Also six different places in which the child acts, represented in didactic handouts "Kabata” (Pocket) - kindergarten, street, room, shop, field, wood - give opportunities to communicate in various communicative situations. It is important that the child has a possibility to imagine himself/herself in definite surroundings and improve speaking skills, being a participant of the situation.

Task structure and their formulation in the analyzed teaching resources reveal that they are based on communicative approach: an important role is given to meaning and the use of language; grammar and vocabulary are studied indirectly in interactive learning activities and real-life situations. Teaching aid "Tip Top", for example, for learning new words and phrases on the theme $U z$ ielas [In the street], provides the following class organizing advice: "Learn in real-life situation - outdoors. The teacher organizes walking down the street. Children watch what is happening, and talk about it. If it is not possible, then they simulate street situation indoors. Children go into characters of street traffic participants, play out different situations and develop speaking skills, needed to act out dialogues, using communicative phrases: Stā̃i!, Gaidi!, Ejam!, sarkanā (zaḷā) krāsa, autobuss brauc, gājeji iet u. c. " [Stand! Wait! Let us go! red (green) colour, bus is going, pedestrians are walking] (Eglite, 2012a, p. 30). The chosen learning methods, techniques and forms of work organization promote the inclusion of each child in the process of language acquisition. Children are included in performing tasks, which vary as to difficulty levels or as to quantity of lexis to be acquired. For example, in the study aid "Tip top" every theme is followed by additional vocabulary for children with previous knowledge: „Considering children knowledge and skill level, teacher additionally in classes teaches other words. .. and phrases." (Eglìte, 2012a, p. 23). Pictures and illustrations are in different colors, understandable, in corresponding 
color range, providing clearness, remembering and the development of creativity. In many tasks children are implied to draw, color, they are offered opportunity to cut, glue and arrange pictures in order to provide for the development of minor muscles and the acquisition of Latvian, employing their senses. X preschool education teacher indicated, however, that "it takes a long time for children, they cannot cover necessary themes".

In Latvian classes, communication is considered as the main goal of the use of language, first listening a lot and then imitating. We can observe both the theory of behaviorism (children are asked first to listen to new words, looking at the objects or pictures, designating them, then repeat) and the theory of communicative competence (children, for example, listen to a short story about a picture, afterwards they are asked to answer the questions about it).

In the analyzed materials and in the study process the presence of the usagebased theories is less observed. We can presume that the revision of the learning material covered is respected, for example, in the teaching aid "Tip top" it is said: "..this week it is advisable to revise previously learned words and phrases, using chants, songs and movement games from the previous classes" (Eglite, 2012a, p. 46). In didactic handouts "Kabata”, in turn, in different games the same words are used.

Also the teacher of Latvian starts her lesson with the revision of words studied previously. In our opinion, the authors of teaching resources, as well as Latvian language teachers should more and more systematically support the acquisition of new knowledge on revision. We advise: 1) more frequent revision of different language units in different combinations, for example, pērk maizi [buy bread] [darb. v. + akuz.] (verb + objective case), the formation of the groups of analogous words: pērk veikalā [buy at shop] [darb. v. + lok.] (verb + locative case) and their addition with new language units: pērk maizi veikalā [buy bread at shop] [darb. v. + akuz. + lok.] (verb + objective case + locative case); 2 ) the use of different constructions, for example, a simple sentence with three nouns [L] (N) and a verb [D] (V) is possible in three word order combinations: [LLDL] (NNVN) - Meitene lelli dod zénam [The girl a doll gives to the boy], [LDLL] (NVNN) - Meitene dod lelli zénam [The girl gives a doll to the boy], and [LDLL] (NVNN) - Zènam dod lelli meitene [To boy gives a doll the girl]; the formation of analogues constructions and their addition with new language units. Considering the importance of frequent and regular use of definite forms for the acquisition of grammar and new word stock, we think that it is necessary to develop a lot of exercises in which children can practice revision, taking as the foundation repeated usage of concrete forms and constructions in different situations.

Only to a slight extent in the form of draft in the teaching aid "Tip top" we can trace the influence of the "other" language, i.e. the issues of positive transfer. For example, in the 1st week class the teacher shows the children a well-known object, the pronunciation of which is similar in both languages, e.g. väze, kaktuss [vase, cactus], but in the 2nd week learning material (theme „Family") it is anticipated that children hear words, which are similar in Latvian and Russian. Neither in the didactic handouts "Kabata”, nor in the lessons this aspect is emphasized. We realize that negative transfer (interference) issues are not stated in any of the analyzed materials, 
but X pre-school education establishment teacher admits that "problems arise in the acquisition of grammatical forms: in the formation of the plurals of nouns, in the agreement of noun and adjective in plural, because they differ from forms in native language". To prevent this and similar drawbacks, we advise that research in present and possible errors in children's second language (Latvian) would be useful, as well as the introduction in the teaching resources of special exercises and advice for teachers, considering the prevention of such mistakes.

The analysis of the content of preschool education Programs, teaching resources, and Latvian as second language lessons has shown that in learning Latvian as second language dominates communicative approach, emerging from abovementioned theory of communicative competence and systemic functional grammar. We can observe the use of the basic principles of the theory of behaviorism as well. Only to a slight extent in the form of draft in the analyzed materials we can trace the use of the usage-based theories.

\section{CONCLUSIONS}

In the $20^{\text {th }}$ and 21 st centuries in linguistics theoretical basic principles of language research were worked out, and the language system was analyzed and characterized. All this has emerged as an important theoretical basis for language acquisition, and has influenced the research of child second language too.

For successful study process more useful are the theories of communicative competence and systemic functional grammar, providing the child with the possibility of acquiring authentic language usable in everyday situations, as well as the usage-based theories, which promote faster and more productive acquisition of the second language, emphasizing general cognition processes and language acquisition mechanisms (frequency, analogy, the choice of word forms), and the influence of the "other" language.

In Latvian preschool age minority children second (Latvian) language study programs and teaching resources we can observe the reflection of the theory of communicative competence, in didactic handouts „Kabata” (Pocket): the use of functional grammar, but in study process: both the basic principles of the theory of behaviorism and the theory of communicative competence. In the analyzed materials and in study process only to a slight extent we can notice the insights of the usage-based theories.

In accordance with the insights of the usage-based theories on the role of input in faster and more thorough language acquisition, we recommend to introduce in teaching resources more frequent revision of the same language material in different situations and in new combinations: in learning content as a whole, in separate theme or lesson.

Both in developing teaching resources and organizing lessons we recommend to put more emphasis on and give more consideration to positive and negative transfer (interference), that is consistent with the views of the usage-based theories followers on the impact of the "other" language teaching language. Currently, this aspect is not given sufficient attention. For filling this gap we suggest that rese- 
arch in present and possible errors in children's second language (Latvian) would be useful. For error prevention we propose developing special exercises, as well as providing methodological recommendations for the teachers of the Latvian language.

\section{REFERENCES}

Beikers, K. (2002). Bilingvisma un bilingvōlās izglìtïbas pamati [The basics of bilingualism and bilingual education]. Rīga: Nordik.

Blom, E., Paradis, J., \& Duncan, T. S. (2012). Effects of Input Properties, Vocabulary Size, and L1 on the Development of Third Person Singular -s in Child L2 English. Retrieved from http://www.ualberta. ca/ jparadis/Johanne_Paradis_Homepage/Publications_files/BPSD_LL.pdf.

Celitāne, C. (2007). Otrās valodas apguve: metodes un pañēmieni [Second Language Acquisition: Methods and Techniques]. Rìga: Pētergailis.

Chomsky, N. (2006). Language and Mind. New York: Cambridge University Press.

Eglìte, I. (2012a). Tip top: 6 gadi: latviešu valoda mazākumtautību bērniem: skolotāja grāmata [Tip top: 6 years: Latvian for minority children: Teacher Book]. Rīga: Zvaigzne ABC.

Eglìte, I. (2012b). Tip top: 6 gadi: latviešu valoda mazākumtautību bērniem: darba kartes [Tip top: 6 years: Latvian for minority children: Worksheets]. Rīga: Zvaigzne ABC.

Ellis N. (2013). Emergentism. In: C. A. Chapelle (Ed.), The Encyclopedia of Applied Linguistics. Vol III (pp. 1874-1875). New Jersey: Blackwell Publishing.

* HGçV1 7 \%HOOHW \& \& $\mathrm{ABC}$.

Halliday, M. (1973). Explorations in the Functions of Language. London: Edward Arnold.

Krashen, S. (1982). Principles and Practice in Second Language Acquisition. Oxford: Pergamon.

Laiveniece, D. (2000). Valodas metodikas didaktiskie jautäjumi [Didactic issues of language methodology]. Rīga: RaKa.

Laiveniece, D. (2002). Lingvokomunikatīvā pieeja: kompetences jēdziena saturs dzimtās valodas mācībās pamatskolā [Lingual communicative approach: the content of competence notion in native language learning at primary school]. Vārds un tā pētišanas aspekti : zinātnisko rakstu kräjums, 6, 230-239. Lazdina, S., Salme, A. (2008). Latviešu valodas apquve mazākumtautību izglìtībā: tendences, attistiba, ietekmes [Acquisition of the Latvian language in minority education]. Retrieved from: http://www.valoda.lv/downloadDoc_683/mid_725.

MacWhinney, B. (2008). A Unified Model of Language Acquisition. Retrieved from: http:/ / www.learnlab. org/uploads/mypslc/ publications/ unified.pdf.

Mickeviča, S., Visocka, A. (2008). Bilingvālà izglìtiba: pasaules un Latvijas pieredze [Bilingual education: world and Latvian experience]. Rīga : LVAVA.

Programma (2012) [Program 2012] = Mazākumtautỉbu pirmsskolas izglìtibas mācību satura programma (ar krievu mäcibu valodu) [Minority Preschool Education Program (with instruction in Russian]. Retrieved from: http://visc.gov.lv/vispizglitiba/saturs/dokumenti/programmas/pirmsskolai/ programma_mzkt_pirmsk_krievu.pdf.

Programma (2008) [Program 2008] = Riggas X pirmsskolas izglïtïas iestäde. Latviešu valodas programma [Latvian Language Program of Riga X preschool education institution].

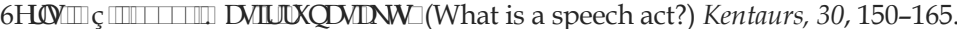

Šalme, A. (2013). Latviešu valodas kā svešvalodas apguves pamatjautäjumi [Key issues of Latvian language acqusition as a foreign language]. Retrieved from: http://bilingvals.lv /uploads_docs/ Met_LAT_3.pdf.

Tomasello, M. (2006). Construction Grammar For Kids. Retrieved from: http:/ / findpdf.net/reader/Construction-Grammar-For-Kids-Construction- Grammar-For-Kids.html

Valdmane, L. (2012). Kabata: mācỉbu lidzeklis latviešu valodas apguvei: 4-7 gadi [Pocket : study aid for the acquisition of Latvian]. Rīga: LVA. 